\title{
Working with Dr. Lindberg: A Personal Perspective
}

\author{
Janet LAYLOR ${ }^{1}$ \\ U.S. National Library of Medicine (retired)
}

\begin{abstract}
Keywords. U.S. National Library of Medicine, Donald A.B. Lindberg M.D., National Institutes of Health, transgender
\end{abstract}

\section{Introduction}

A large organization like the U.S. National Library of Medicine (NLM) often reflects the personality or character of the person who runs it. In Donald A.B. Lindberg M.D.'s case, it was more akin to character. I rarely came across anyone who did not look forward to coming to work, myself included. My peers not only enjoyed what they did, they were also in an environment in which they received an opportunity to thrive.

I joined NLM in December 1988, a few years after Dr. Lindberg became NLM's director. I met him about six years later because of his preference for Apple products and my expertise. Dr. Lindberg eventually asked me to be his technical support assistant and help him (and his immediate staff) with hardware and software issues. Always professional, we rarely interacted personally other than an occasional foray into current events. Then, about six years later, I was forced to involve him in my personal life when I initiated a transition from male to female.

\section{Tolerance Prevailed}

NLM was a socially advanced entity, in large part because of Dr. Lindberg. People were very comfortable being 'out' as gays or lesbians. It was evident that the white male hierarchy - omnipresent at the time of Dr. Lindberg's arrival - was shifting to include women and minorities among NLM's staff and management. Yet when I came out as a transgender woman, I knew there were few legal protections and institutional precedents. I was concerned about my career and very survival. During the initial months of my transition, two other institutes at the U.S. National Institutes of Health had fired two employees during their gender transition.

To back up, throughout my employment at NLM, I was an at-will contractor, which meant I could be dismissed without reason or explanation. Also, transgender was not a federally protected class at the time of my transition. Moreover, besides coming out to Dr. Lindberg and my immediate co-workers, I informed NLM's offices of personnel and employee services about my plans. To this day, I am struck by the consistent response I received from all: 'You will not be fired for this.'

\footnotetext{
${ }^{1}$ Corresponding author: jlaylor@gmail.com
} 
These simple words indicate NLM's senior management's character and integrity and suggest a reason why so many people admired and were loyal to Dr. Lindberg. Essentially his position was: 'there are things that you can do or not do that can and will get you fired, but who you are will never be one of them.'

My peers and I could be as quirky, different, and unique as we wanted to be, yet we were judged by the quality of our work and contributions. Indeed, Dr. Lindberg's straightforward managerial philosophy - and its tolerant underpinnings - partially explain a prevailing ethos that supported many of NLM's core achievements during his tenure. The latter include Medline, Medline Plus, Grateful Med (more on that in a moment), PubMed, Visible Human, and dozens of other projects.

\section{About Dr. Lindberg}

Overall, Don Lindberg may have been lauded, but he was not an egomaniac. He was HIGHLY opinionated but rarely ignored other people's ideas. His interest in seeing others succeed fostered shared responsibility, recognition, and independence. For example, after a vigorous defense of their plans and ideas, Dr. Lindberg provided significant autonomy to NLM's History of Medicine, High-Performance Computing Laboratory, and Special Information Services divisions in addition to diverse outreach and extramural programs that are discussed in this book's first three sections. The world (yes, the world - Dr. Lindberg would have loved for it to have been called the International Library of Medicine) is a better place for the contributions developed at NLM during his tenure.

Also, Dr. Lindberg's tolerance, openness to innovation, and interest in others generated other constructive institutional outcomes. For example, when Roy Standing (from NLM's Office of Computer and Communication Systems) developed MEDLINE's initial software, he suggested to Dr. Lindberg that it be called 'Grateful Med' both a pun and homage to the well-known band. Standing had a dry sense of humor that Dr. Lindberg appreciated. He quickly decided that a clever name should be embraced rather than quashed - even within an evidence-based federal health agency. So, the name 'Grateful Med' survived - and Standing's software (which was well-written) was both supported and sometimes celebrated by its users.

Standing was one of the many retired and active NLM staff members who attended Dr. Lindberg's retirement ceremonies in 2015. Others who attended, including Alexa McCray Ph.D. (who launched ClinicalTrials.gov) and Michael Ackerman Ph.D. (who managed the Visible Human Project), commonly appreciated the autonomy and creative space they received at NLM during Don's tenure.

Indeed, NLM's success derived from Dr. Lindberg's eagerness to see others succeed, his tolerance and support of diversity, and his interest in employee creativity and innovation. I was one of many beneficiaries - and I salute Don's character, contributions, legacy, and memory. 